1. MBBS, MCPS, FCPS

Assistant Professor Paediatrics Shaheed Muhtrama Benazir Bhutto Medical College

Layari General Hospital Karachi.

2. MBBS, DCH, FCPS, MRCPCH

Assistant Professor Pediatrics

Hamdard College of Medicine and

Dentistry

Hamdard University Hospital,

Karachi.

3. MBBS, FCPS

Assistant Professor Paediatrics

Hamdard College of Medicine and Dentistry

Hamdard University Hospital,

Karachi.

4. MBBS, FCPS

Assistant Professor Pediatrics

Dow University of Health Sciences/

Civil Hospital Karachi.

5. MBBS, MD

Associate Professor Medicine

Karachi Institute of Medical

Sciences,

Malir Cantonment, Karachi.

6. MBBS, FCPS

Assistant Professor Psychiatry

Dow International Medical College,

Dow University of Health Sciences,

Correspondence Address:

Dr. Nathumal Maheshwari

Department of Paediatrics

Shaheed Muhtrama Benazir Bhutto

Medical College

Layari General Hospital Karachi.

drnathumal@gmail.com

Article received on:

04/11/2019

Accepted for publication:

$13 / 04 / 2020$

\section{Serum calcium level in neonatal seizures presenting at a Tertiary Care Hospital.}

Nathumal Maheshwari' ${ }^{1}$, Nadeem Noor ${ }^{2}$, Adnan Bashir $^{3}$, Bilawal Hingorjo ${ }^{4}$, Arshad Ali5 $^{5}$, Urooj Tabassum ${ }^{6}$

ABSTRACT... Objectives: The present study was conducted to detect serum calcium level in neonatal seizures presenting at a Tertiary Care Hospital. Study Design: Case control study. Setting: Department of Paediatrics, Shaheed Muhtrama Benazir Bhutto Medical. College Layari General Hospital, Karachi, Sindh. Period: June 2017 to January 2018. Material \& Methods: The sample comprised of 100 cases and 100 controls that were selected through nonprobability purposive sampling through inclusion and exclusion criteria. Sera were separated through centrifugation of blood for measuring the serum calcium levels. Data was analyzed on SPSS software (SPSS ver 22.0, IBM, Incorporation, USA) at 95\% confidence interval ( $\leq \leq 0.05)$. Results: Of 100 cases and 100 controls, the male and female were noted as 61 vs. 57 and 39 vs. 43 respectively $(P>0.05)$. In cases, the mean \pm SD $\mathrm{Ca}++$ was noted as $4.17 \pm 1.58$ $\mathrm{mg} / \mathrm{dl}$ while in control it was noted as $8.15 \pm 1.05 \mathrm{mg} / \mathrm{dl}$. Ca ++ levels as low as $3.07 \mathrm{mg} / \mathrm{dl}$ were noted in the neonatal seizure cases. Normocalcaemia was noted in 81 controls vs. 11 cases and hypocalcaemia in 18 controls vs. 89 cases. Conclusion: The present study reports hypocalcemia is common in neonatal seizures. Pediatricians must evaluate for timely correction of serum calcium to prevent long term neurological sequelies.

Key words: $\quad$ Neonates, Neonatal Seizures, Serum Calcium, Sindh.

Article Citation: Maheshwari N, Noor N, Bashir A, Hingorjo B, Ali A, Tabassum U. Serum calcium level in neonatal seizures presenting at a Tertiary Care Hospital. Professional Med J 2021; 28(2):181-186.

https://doi.org/10.29309/TPMJ/2021.28.02.4319

\section{INTRODUCTION}

Seizure is one of commonest neurological manifestation of biochemical disturbance in neonates presenting in emergency room. Seizures occur because of a numbers of causes. Neonates are at particular risk of seizures because of metabolic, infectious, toxic and congenital disorders. ${ }^{1}$ Manifestation of neonatal seizure is extremely subtle., ${ }^{1,2}$ Neonatal seizure presenting with multiple signs such as lip smacking, cycling movements, eye blinking, eye deviation, nystagmus, and respiratory rate problem such as apnea may the presenting manifestations that are sometimes difficult to discriminate from normal neonatal movement. ${ }^{1,3}$ A $20 \%$ prevalence of seizure has been reported in neonates in intensive care unit. ${ }^{4,5}$ However, neonatal seizure prevalence ranges from as low as $0.5 \%$ in full term babies to as high as $21 \%$ in preterm (premature) babies. ${ }^{6,7}$ Seizure is not a diagnosis but a sign of an underlying abnormality that may be systemic or biochemical in nature. ${ }^{7}$ Biochemical disturbance of electrolytes are frequent in the neonatal seizure. Sometimes it is difficult to control and further neuronal damage may occur if treatment is delayed. Early recognition and prompt correction of biochemical disturbances is necessary for the satisfactory long term outcome. ${ }^{5}$ Biochemical disturbances of clinical significance that predispose to seizures include the; electrolyte imbalance and hyperbilirubinemia, etc. Electrolyte disorders include the hyponatremia and hypernatremia, hypokalemia and hyperkalemia, hypomagnesaemia, hypoglycemia, hypocalcaemia and hypercalcemia. ${ }^{7,8}$ of these biochemical abnormalities, the hypocalcaemia 
is by far the most common in inducing neonatal seizure. Hypocalcaemiaisthemostcommoncause of neonatal seizure followed by hypoglycemia and hypomagnesaemia. ${ }^{5}$ Hypocalcaemia may manifest clinically as neuronal hyper- excitability and seizure, neuromuscular excitability called tetany and delirium. Spontaneous neuronal excitability is rule with hypocalcaemia and a common predisposing factor of brain seizures. ${ }^{9,10}$ Hypocalcaemia is defined as serum $\mathrm{Ca}++$ levels $<7 \mathrm{mg} / \mathrm{dll}^{7}$ Various mechanisms have been proposed by which the hypocalcaemia predisposes to seizure through neuromuscular excitation. One proposed mechanism is spontaneous neuronal depolarization caused by spontaneous $\mathrm{Na}+$ channels opening of in the presence of hypocalcaemia. ${ }^{9,10}$ Hypocalcaemia induced brain seizure is a serious medical emergency of neonates. ${ }^{11}$ Keeping in view, the biochemical abnormality of low serum calcium, there is need to further evaluate the gravity of a simple problem evoluting in serious clinical condition of brain seizures in newborn. There is dire need to highlight the issue of brain seizure in neonates and readdress its simple management through correction of serum calcium. The present prospective study addresses on the serum calcium levels in neonatal seizures presenting at a tertiary care hospital.

\section{MATERIAL \& METHODS}

This case control study took place at the Department of Paediatrics, Shaheed Muhtrama Benazir Bhutto Medical College Layari General Hospital, Karachi, Sindh from June 2017 to January 2018. Neonates were selected according to inclusion and exclusion criteria presenting at the Department of Pediatrics of our tertiary care hospital. Pediatric Department is fully equipped with a neonatal intensive care unit. All facilities are available therein. 200 neonates were recruited through non-probability convenient sampling according to inclusion and exclusion criteria.

Neonates were divided into cases $(n=100)$. Inclusion criteria for cases were defined as those babies presenting with seizures with apparently no detectable problem, had no history of fever, septicemia, birth asphyxia and injuries and no other obvious cause of convulsion detected. Another 100 neonates $(n=100)$ were labeled as control. Inclusion criteria for control were; those babies presenting with seizures with detectable problem such as fever, septicemia, meningitis, and any other illness who were admitted to neonatal ICU without any convulsion. Informed consent was taken from the parents/ guardians. Study protocol was approved by the institutional ethical committee according to the Helsinki's declaration for conducting human research. History was taken from the parents/ attendants/guardians about presenting illness. Peri-natal history, family history of epilepsy, past seizures, economic status was noted. Neonates were examined physically. Authors designed a proforma for data to be noted in it. Serum $\mathrm{Ca}++$ level $<7 \mathrm{mg} / \mathrm{dl}$ (1.75 mmol/L) was defined as hypocalcemia. ${ }^{7}$ Neonatal seizures were treated by diazepam $(0.5 \mathrm{mg} / \mathrm{kg})$ parenteral $/$ per rectal. Once seizures were over, venesection was performed. $2 \mathrm{ml}$ blood was taken from peripheral vein. Sera were separated from blood by centrifuging at 3000 rpm (10 minutes). Serum calcium was estimated by "Colorimetric method". ${ }^{12}$ Colorimetric method is based on the serum $\mathrm{Ca}++$ measurement by chelating with EDTA in the presence of "murexide indicator". Readings were noted at filter peak of 5750-5800 A on an EEL photoelectric titrator. Confidentiality of data was maintained. Ethical permission was taken from institute and consent form was signed by parents/guardians. Data was typed on Microsoft Excel sheet. This was copied and pasted on SPSS sheet (SPSS ver 22.0 for windows, IBM, Incorporation, USA) and analysis was performed. Cross tabulation was applied for Chi square for the categorical data. Results were presented as frequency and \%. Independent samples Student's t-tests was applied to continuous variables and results were presented as mean and standard deviation (SD). Confidence interval of significance was taken at 95\% ( $\mathrm{P} \leq 0.05)$.

\section{RESULTS}

Age (mean \pm SD) in cases and controls was 3.2 \pm 0.5 days and $3.1 \pm 0.03$ days respectively $(P>$ 0.05). Seizure frequency is shown in Table-l. 94 controls showed convulsion frequency of $<1$ 
while 84 cases showed $\geq 4$ convulsions (Table-l) $(p=0.0001)$. Nature of convulsions was; focal in $37 \%$, subtle in $31 \%$ and mixed in $32 \%$ of cases (Figure-1). Duration of convulsions is shown in Table-II. Duration of $<5$ minutes seizures in controls were noted in 7 and in cases in 73 . In cases, 27 babies showed duration of 5- 30 minutes. Of 100 cases and 100 controls, the male and female were noted as 61 vs. 57 and 39 vs. 43 respectively (Figure-2) $(P>0.05)$. TableIII (Figure-3) shows the calcium distribution of control and cases. In cases, the mean \pm SD Ca++ was noted $4.17 \pm 1.58 \mathrm{mg} / \mathrm{dl}$ while in control it was noted as $8.15 \pm 1.05 \mathrm{mg} / \mathrm{dl}$. Ca++ levels as low as $3.07 \mathrm{mg} / \mathrm{dl}$ were noted in the neonatal seizure cases. Normocalcaemia was noted in 81 controls vs. 11 cases and hypocalcaemia in 18 controls vs. 89 cases as shown in Table-IV (Figure-4).

\begin{tabular}{|c|c|c|c|}
\hline Frequency & Control & Cases & P-Value \\
\hline 0 & 51 & 0 & \\
\hline$\leq 1$ & 43 & 3 & \multirow{6}{*}{0.00001} \\
\hline 2 & 6 & 2 & \\
\hline 3 & 0 & 11 & \\
\hline 4 & 0 & 31 & \\
\hline$\geq 5$ & 0 & 53 & \\
\hline Total & 100 & 100 & \\
\hline
\end{tabular}

Table-I. Frequency of neonatal seizure in control and cases

\section{Nature of seizure in cases}

$31 \%$

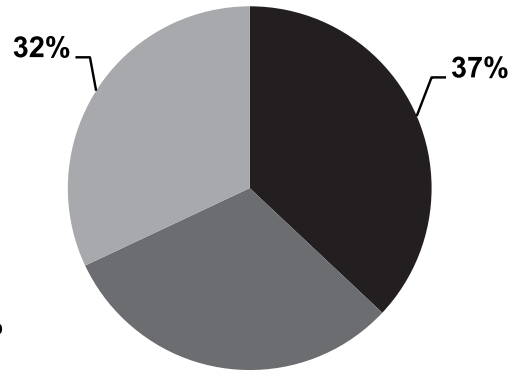

Focal

Subtle

Mixed

Figure-1. Nature of seizures in cases

\begin{tabular}{|l|c|c|c|}
\hline \multicolumn{1}{|c|}{ Duration } & Control & Cases & P-Value \\
\hline$<5$ minutes & 7 & 73 & \multirow{2}{*}{0.0001} \\
\hline 5 5- 30 minutes & 0 & 27 & \\
\hline
\end{tabular}

Table-II. Duration of seizures in control and cases

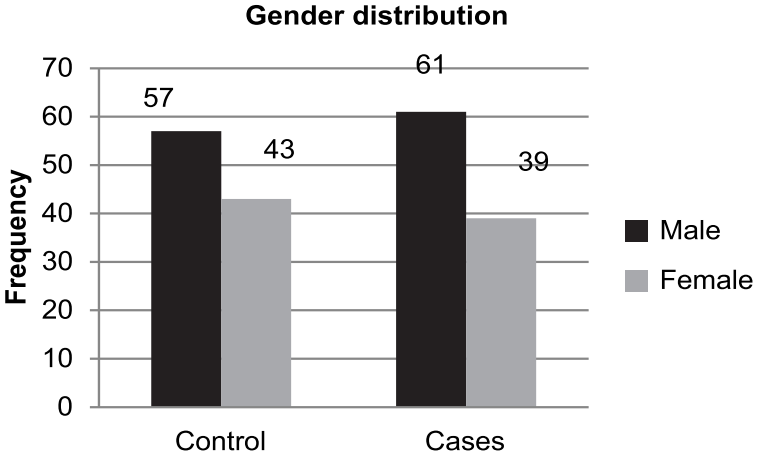

Figure-2. Bar graph showing gender distribution

\begin{tabular}{|c|c|c|c|}
\hline Serum $\mathbf{C a}++(\mathbf{m g} / \mathbf{d l})$ & Control & Cases & P-Value \\
\hline$\leq 3.9$ & 1 & 13 & \\
\hline $4-4.9$ & 1 & 25 & \\
\hline $5-5.9$ & 3 & 21 & \\
\cline { 1 - 3 } $6-6.9$ & 13 & 30 & \multirow{2}{*}{0.00001} \\
\hline $7-7.9$ & 31 & 7 & \\
\hline$\geq 8.0$ & 51 & 4 & \\
\hline Total & 100 & 100 & \\
\hline
\end{tabular}

Table-III. Serum calcium levels in in control and cases

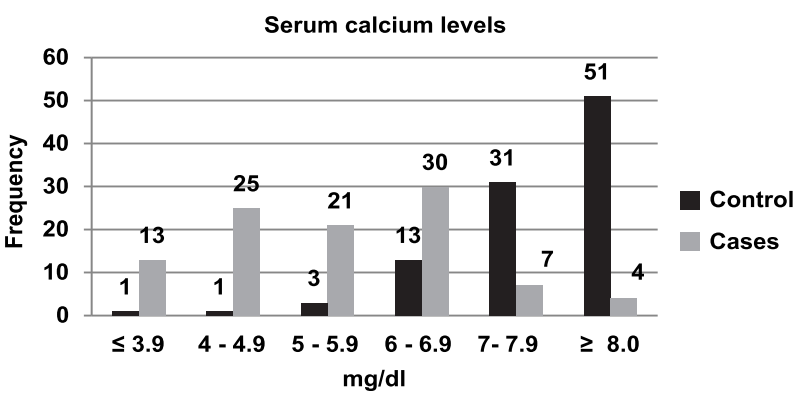

Figure-3. Bar graph showing frequency of calcium levels

\begin{tabular}{|l|c|c|c|}
\hline & Control & Cases & P-Value \\
\hline Hypocalcaemia & 11 & 93 & \\
\hline Normocalcaemia & 89 & 7 & 0.00001 \\
\hline Total & 100 & 100 & \\
\cline { 1 - 2 } Table-III. Hypocalcaemia and Normocalcaemia in \\
control and cases
\end{tabular}




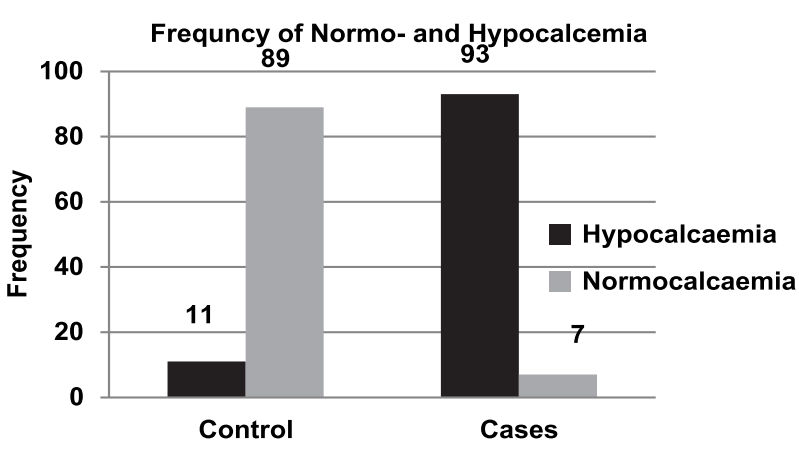

Figure-4. Bar graph showing frequency of Normo- and hypocalcaemia

\section{DISCUSSION}

A search of literature shows, this is the first study being reported from out tertiary care hospital on the serum calcium levels in neonatal seizures presenting with afebrile fits. The cases were compared with age and gender matched controls and those suffering from neonatal seizures were having no apparent cause of convulsion. Of 100 cases and 100 controls, the male and female were noted as 61 vs. 57 and 39 vs. 43 respectively ( $P$ $>0.05)$. This is consistent to previous studies..$^{3-8}$ In present study, the hypocalcemia was noted in $89 \%$ of cases of neonatal seizures compared to $11 \%$ in controls. While $81 \%$ of controls showed normocalcemia compared to $11 \%$ neonatal seizure cases (Table-IV). Our finding of $89 \%$ hypocalcemia in neonatal seizures is consistent with previous studies. ${ }^{3-8}$ Consensus is lacking on the cut off value of serum calcium level as hypocalcemia.

Literature does not show evidence of exact serum calcium levels that defines neonatal hypocalcemia. ${ }^{7,8}$ Various cut off values are defined such as serum $\mathrm{Ca}++<8 \mathrm{mg} / \mathrm{dl}^{8},<7.5 \mathrm{mg} / \mathrm{dl}$ and $<7 \mathrm{mg} / \mathrm{dll}^{6,7}$ Baten et $\mathrm{al}^{13}$ conducted a study on serum calcium levels in neonatal seizures with 50 cases and reported hypocalcemia in $60 \%$ of cases. The finding is in agreement with present however, less percentage of above study ${ }^{13}$ may be due to small sample size. Cockburn et al ${ }^{8}$ conducted a longitudinal study of 2 years duration on neonatal convulsions. They reported primary defect of mineral metabolism in $55 \%$ of neonatal convulsions. The findings of present study are more prevalent found in $89 \%$ hypocalcemia in neonatal seizures. This may be due to the fact that the vitamin $D$ deficiency is prevalent in the country ${ }^{14,15}$ and there is no data in this regard on the neonatal seizures. The mothers lacking vitamin D may give birth to hypocalcemia neonates. Another study by Kumar et $\mathrm{al}^{16}$ reported primary metabolic disorder in $25 \%$ of cases of neonatal seizures. This frequency is very small and is inconsistent with present and previous studies. ${ }^{8,13}$ Approximately, 94 controls showed convulsion frequency of $<1$ while 84 cases showed $\geq 4$ convulsions $(p=0.0001)$. Nature of convulsions was; focal in $37 \%$, subtle in $31 \%$ and mixed in $32 \%$ of cases. The findings are supported by previous studies. ${ }^{8,14}$ In developing countries, the metabolic cause of neonatal seizure is due to malnourished mothers, infrequent breast feeding, delayed breast feeding and faulty feeding practices. This is in contrast to studies form western countries ${ }^{16}$, where breast feeding practices have made this problem very uncommon.

A previous study 6 reported the hypocalcemia is very common in neonates in developing countries mainly due to primary metabolic abnormalities. Similar findings have been reported from western countries. ${ }^{16}$ Sood et $\mathrm{al}^{5}$ reported from India that the hypoglycemia is common cause of neonatal followed by hypocalcaemia. This is in contrast to present and previous studies. ${ }^{6,8,13}$ In present study, $11 \%$ of controls were suffering from hypocalcemia that is comparable to the Baten et $\mathrm{al}^{13}$ that noted in $20 \%$ of control. In present study, the duration of $<5$ minutes seizures in controls were noted in 7 and in cases in 73. In cases, 27 babies showed duration of 5- 30 minutes. The findings are in agreement with previous studies. ${ }^{7,13}$ Duration of neonatal seizure of $>30$ minutes indicates poor prognosis., ${ }^{73}$ In present study majority of cases were having duration of seizure of $<5$ minutes that is consistent with a previous study. ${ }^{13}$ In present study, mean \pm SD $\mathrm{Ca}++$ was noted $4.17 \pm 1.58 \mathrm{mg} / \mathrm{dl}$ in cases while in control it was noted as $8.15 \pm 1.05 \mathrm{mg} / \mathrm{dl}$. $\mathrm{Ca}++$ levels as low as $3.07 \mathrm{mg} / \mathrm{dl}$ were noted in the neonatal seizure cases. The findings are in agreement with previous studies. ${ }^{13,17-19}$ Baten et $\mathrm{al}^{13}$ reported mean serum $\mathrm{Ca}++$ level of $1.62 \pm .29$ in cases that was less than in controls $2.07 \pm .30 \mathrm{mml} / \mathrm{L}$ and 
difference was statistically significant $(p<0.0001)$. Another previous study ${ }^{17}$ conducted with cases of neonatal seizure, reported high incidence of hypocalcaemia in full term and premature infants. Similar is another previous study ${ }^{18}$ high incidence of hypocalcemia induced convulsion. Above studies $^{13,17,18}$ are in support with the findings of our present study. A recent study ${ }^{19}$ reported high incidence of hypocalcemia in neonatal seizures admitted in level III neonatal intensive care units. Recent studies by Elsary et $\mathrm{al}^{20}$ and Do $\mathrm{HJ}$ et $\mathrm{al}^{21}$ have reported neonatal hypocalcemia and neonatal seizures and support the findings of present study. The limitations of present study include; first- small sample size, second- poor ethnical group of sample population was selected, third- other variables were not measured due to financial issues. However, the strength of study lies in its prospective study design and inclusion criteria. The findings of present are worth to report and will add much to the literature on the topic of neonatal seizures and hypocalcemia. Large sample size studies are recommended to be conducted in the future along with associated factors like race, ethnicity and geography.

\section{CONCLUSION}

The present study reports hypocalcemia is very common metabolic defect in neonatal seizures, where other cause is not identified. Early recognition and prompt correction of serum calcium may prevent against the long term neurological sequelies. Clinical practitioners should be aware of a common modifiable defect of hypocalcemia. Further large scale studies are warranted to dig into the gravity of the problem and this will help making national guidelines for neonatal seizures.

Copyright(C) 13 Apr, 2020.

\section{REFERENCES}

1. Thomas TC, Smith JM, White PC, Adhikari S. Transient neonatal hypocalcemia: Presentation and outcomes. Pediatrics 2012; 129:e1461-7.

2. Cho WI, Yu HW, Chung HR, Shin $\mathrm{CH}$, Yang SW, Choi $\mathrm{CW}$, et al. Clinical and laboratory characteristics of neonatal hypocalcemia. Ann Pediatr Endocrinol Metab 2015; 20:86-91.
3. Sperling MA. Pediatric Endocrinology. 4th edition. Philadelphia: WB Saunders Co., 2014:734.

4. Malik R, Mohapatra JN, Kabi BC, Halder R. 5-Hydroxy Cholecalciferol Levels in Infants with Hypocalcemic Seizures. J Nutr Food Sci 2014, 4:3.

5. Sood A, Grover N, Sharma R. Biochemical abnormalities in neonatal seizures. Indian $\mathrm{J}$ Pediatr 2003; 3:221-24.

6. Cheung ENM, George SR, Andrade DM, Chow EWC, Silversides CK, Bassett AS. Neonatal hypocalcemia, neonatal seizures, and intellectual disability in 22q11.2 deletion syndrome. Genet Med 2014; 16 (1): 40-44.

7. Kliegmen RM. Fetal and Neonatal Medicine. In: Behrman RE, Kilegmen RM. Nelson Essentials of Paediatrics $10^{\text {th }}$ edition. Philadelphia WB Sunders company 2014: 202-6.

8. Cockburn F, Brown JK, Belton NR, Forfar JO. Neonatal Convulsions associated with primary disturbance of calcium, phosphorous and magnesium metabolism. Arch of disease of childhood 1973; 48:99-108.

9. Liaqat S, Zubair A, Noor T, Waseem R. Hypocalcemia: Underlying Factors in Rural Area. PJMHS 2016; 10(4): 1110-11.

10. Kakajiwala A, Barton KT, Rampolla E, Breen C, Pradhan M. Acute hypocalcemic and metabolic alkalosis in children on cation exchange resin therapy. Hindawi Case Reports Nephrol 2017; Article ID 6582613: 1- 5.

11. Han P, Trinidad BJ, Shi J. Hypocalcemia - induced seizure: Demystifying the calcium paradox. ASN Neuro 2015: 1-9.

12. Lazarevic V,Pothula $S$, Andres-Alonso $M$, Fejtova A. Molecular mechanisms driving homeostatic plasticity of neurotransmitter release. Frontiers Cell Neurosci 2013; 7:244.

13. Baten LS, Mollah AH, Ali MN, Rahsid MH. Serum Calcium Status of Neonates with Seizure in a Tertiary Care Hospital. Bangladesh J Child Health 2012; 36 (3):122-5.

14. Rehman M, Bajwa FE, Mushtaq MA, Sarwar I, Amir S, Nawaz R. Afebrile seizures; Frequency of hypocalcemia in children presenting with afebrile seizures. Prof Med J 2019; 26(5):836-840.

15. Khan AH, lqbal R, Naureen G, Dar FJ, Ahmed FN. Prevalence of vitamin $D$ deficiency and its correlates: Results of a community-based study conducted in Karachi, Pakistan. Arch Osteoporos 2012; 7(1- 2):27582. 
16. Kumar A, Gupta V, Kachhawaha JS, Singla PN. Biochemical abnormalities in neonatal seizure. Indian J Pediatr 1995; 323: 424-8.

17. Stoliar O, Largnia M, Languia AE, Ruiz B. Studies in $\mathbf{1 1 5}$ neonates with one minute Apgar score of three or less: Early neonatal hypocalcaemia. J Pediatr 1971; 78:906.

18. Jajoo D, Kumar A, Shankar R, Bhargana V. Effect of birth asphyxia in serum calcium levels in neonates. Indian J pediatr 1995; 62: 455-9.
19. Shrinath G, Rajesh N, Laveesh M R. Incidence of early onset hypocalcaemia in newborns admitted in level III NICU. Int J Med Paed Oncol 2017:3(4): 180-182.

20. Elsary AY, Elgameel AA, Mohammed WS, Zaki OM, Taha SA. Neonatal hypocalcemia and its relation to vitamin D and calcium supplementation. Saudi Med J 2018; 39 (3):247-53.

21. Do HJ, Park JS, Seo JH, Lee ES, Park CH, Woo HO, et al Neonatal Late-onset Hypocalcemia: Is There Any Relationship with Maternal Hypovitaminosis D? Pediatr Gastroenterol Hepatol Nutr 2014; 17(1):47-51.

\begin{tabular}{|c|c|c|c|}
\hline \multicolumn{4}{|c|}{ AUTHORSHIP AND CONTRIBUTION DECLARATION } \\
\hline Sr. \# & Author(s) Full Name & Contribution to the paper & Author(s) Signature \\
\hline 1 & Nathumal Maheshwari & $\begin{array}{l}\text { Literature review, initial handling, } \\
\text { complication of resutls, Proof } \\
\text { composing. }\end{array}$ & \\
\hline 2 & Nadeem Noor & $\begin{array}{l}\text { Materal handling, Interpretation, } \\
\text { Proof reading. }\end{array}$ & \\
\hline 3 & Adnan Bashir & $\begin{array}{l}\text { Conceps initial handling, Collec- } \\
\text { tion of materials, Compilation re- } \\
\text { sutl, manuscript. }\end{array}$ & \\
\hline 4 & Bilawal Hingorjo & $\begin{array}{l}\text { Literature review, concept, mate- } \\
\text { rial handling, proof reading. }\end{array}$ & \\
\hline 5 & Arshad Ali & $\begin{array}{l}\text { Concepsts materials handle, in- } \\
\text { terpretation, manuscript write up. }\end{array}$ & \\
\hline 6 & Urooj Tabassum & $\begin{array}{l}\text { Concept, materials handle, Col- } \\
\text { lecton ofmaterials, Compilation } \\
\text { of resutls. }\end{array}$ & \\
\hline
\end{tabular}

